\title{
The Space of Cultural Values in the Modern Russian Literature
}

\author{
Daria A. Funtova* and Sergei B. Sinetskiy \\ Chelyabinsk State Institute of Culture and Arts \\ $36 a$ Ordzhonikidze Str., Chelyabinsk, 454091, Russia
}

Received 02.02.2018, received in revised form 05.06.2018, accepted 12.06.2018

\begin{abstract}
The subject of values is at the cutting edge in humanitarian studies of recent decades. The article provides an insight into the space of cultural values, which the author defines as the social environment limited to a conditional frame of time and place defined by a certain set of values. This concept covers cultural mechanisms of transmission and actualization of values through the communication of various social and cultural actors. The literary process in this case becomes a functional tool for diagnosing the space of cultural values and represents a set of value-oriented relations between the individual and the social environment. The study has identified qualitative changes in the literary space that have occurred over the past three decades, its potential in the formation of the space of cultural values. Social and cultural analysis of the literary works of mainstream contemporary Russian writers Victor Pelevin and Vladimir Sorokin, reveal timely values such as technical and information independence, security of one's own data, protection of individual consciousness from outside interference. In particular, this study considers the value of tolerance, brought up to date by the globalization of cultural space.
\end{abstract}

Keywords: space of cultural values, modern Russian literature, personality, social environment, aesthetic intuition, actualization of values.

DOI: 10.17516/1997-1370-0280.

Research area: culturology.

Contemporary Russian humanitarian scientific discourse extensively illuminates the rapprochement of different social groups, the search for national identity by means of some rallying point. A common place for numerous discussions is the postulate on the need to form a consolidating value centerpiece. A distinctive feature of modern social and cultural reality is the absence of a single factor regulating the axiological field, such as religion, power or total ideology. Traditionally, the enlightened Russian and Soviet society was literary-centered, and the master of the artistic word was "the master of doom", "the teacher of life", and the "engineer of human souls". For the last twenty years Russian literature has experienced difficult times; moreover, the society has often perceived the idea that literature can have a vocal influence on culture as archaic. However, it is difficult to assume that the fundamental tradition that existed for many decades of addressing the book as a mentor, an interlocutor, and a source for ideas could discontinue suddenly with an advent

(C) Siberian Federal University. All rights reserved

* Corresponding author E-mail address: dariafuntova@gmail.com 
of new technical means of communication. Our position is that, despite the declared problems of Russian literature, such as plummeting number of readers, it retains a great biasing potential for Russian society, including modern Russian literature.

The social practice of the last twenty years shows that practically any phenomenon of culture, and therefore literary process, can dominate in the space of cultural values, and thus actualize and obviate certain values. I.A. Surina in her thesis fully considers the methodological grounds for understanding the axiological space of society as a theoretical construction. In her work, she defines value space as "the space of estimates, determined by the subjective perception of social reality. The value space of society establishes the regulation of social interactions in the value dimension and their result" (Surina, 2001: 8). To distinguish the value centerpiece of culture, it is necessary to present a methodological basis for the interaction of its subjects, which in turn prompts us to turn to the concept of the space of cultural values.

In existing scientific studies, M.V. Kovaleva considers the space of cultural values as a representative set of cultural values at a certain point in time (Kovaleva, 2009: 27), while E.O. Orlova describes it as a sphere of ideal value-based goals realized in the process of education (Orlova, 2006: 90). E.A. Tsareva gives the closest definition of the axiological space of culture, which, within the framework of the semiotic approach, denotes it through the semantic field of the symbol as a kind of integrity of the invariant semantic core, mobile semantic layers and productive semantic layer (Tsareva, 2011: 10). Nevertheless, the given definitions do not disclose the functional features of this phenomenon, in particular, leaving behind the cultural mechanisms of the formation and transmission of values.
Basing on the approach of the cultural anthropology, under the space of cultural values we mean the social environment limited to a conditional frame of time and place defined (identified) by a certain combination (set) of values. This definition implies a meaningful communication of various social and cultural actors, mediated by the actual cultural phenomenon, by the specific situation of interaction. In order to approbate such an understanding of the space of cultural values, in this study we apply it to a specific cultural phenomenon, namely, contemporary Russian literature.

Modern Russian literature has transformed significantly in the past three decades due to the objective changes in social and cultural reality. For centuries, Russian literary space had a fairly well ordered and graded structure, usually in the form of some supreme bodies. The latter explicitly or implicitly determined the general level and rather rigid boundaries for literary texts, beyond which they had a minor impact on the mass readership, existing only as marginal and hardto-reach. After the collapse of the Soviet Union, when ideological institutions lost their limiting role, it turned out that the market conjuncture or even some lucky coincidence drew the boundary between the "mainstream" and the "marginal" in literature.

In the early nineties at least four different value components comprised the space of cultural values of Russian literature. The first one was Soviet literature seeking to adapt to the current conditions in the country. The second was the $20^{\text {th }}$ century literature prohibited in the USSR, pioneering among Russian readership only at that time. The third included the post-perestroika literature searching for new themes and artistic techniques. And the last one was Western literature designed mainly as a "commodity product" for the audience with the lowest common denominator. 
This literary array brought the genre diversity of contemporary Russian literature, alongside with the difficulties in its current classification. The second important feature of the Russian literature of the 90s was the influence of market relations established in the country. Publishers could issue a particular literary work, only being confident of its commercial success. This certainly affected the quality level and the general orientation of the whole array of values that literature of those years broadcasted to the masses.

Today, when the transition from the socialist to the capitalist reality is over, Russian literature has managed to serve as an authentic indicator of the state of society. In the conditions of a stabilizing economy, one can see that the market actively shifts to reflecting the space of cultural values, instead of defining it. As noted by M.A. Cherniak: "The first decade of the $21^{\text {st }}$ century literature could be characterized as the variegated, contradictory and multifaceted, as literature now is a high-tech synthesis of art and business that is a consequence of ever deeper integration of culture into the market relations" (Cherniak, 2010: 76). Modern literature becomes an open social and cultural space by escaping its obscene edginess of the post-perestroika period. Writers dispose of shallow and disgraceful manner in their works, in other words, an empty manifestation of antisocial, perverted or unacceptable positions becomes a phenomenon typical for the local literary niche. This happens because Russian society itself is recovering from the radical political and economic changes to enter a new social and cultural reality as its subject, not an observer.

In this part of the article, we would like to examine the complex relationships, which occur between the participants of the literary space, namely the writer, his or her work and the reader. The writer interacts with the reader through the text as a creator, as a social person, and as a participant of the everyday life. The issue of personality engaged into the relationships with a larger-scale cultural phenomenon is a broad subject of cultural studies; in particular, it occupies the central place in works of prominent researchers such as L.N. Kogan, S.N. Ikonnikova, M.S. Kagan and others. The personality of the writer plays a significant role in the process of generation and transmission of values, citing L.N. Kogan: “...a spiritually rich person is both an object and a subject of culture" (Kogan, 1969: 13). The writer has an impact on their readership, presenting certain values in their texts. V.S. Tsukerman in his contemplations about the correlation between the scale of personality and the outreach of cultural space notes "... the extent of this coverage depends on the scale of the subject, the intensity and quality of his cultural activity. In this sense, the cultural space is as curved as the physical one. The greater the "mass" (for example, the scale of the human personality), the greater the curvature of such a space, the more the cultural space becomes the space of a given person" (Tsukerman, 2011: 51). In the context of our study, we consider two impressive personalities who represent the mainstream of the modern literary process - Victor Pelevin and Vladimir Sorokin. These writers have significant size of print run; they receive literary prizes and, importantly, cause ambiguous, but intense public interest. Both authors, being odious and even iconic, create "cultural bridgeheads" (Sinetskii, 2002: 176-177): they have adepts, fan clubs, and their works are screened in Russia and abroad. The scale of these personalities provokes a noticeable "curvature" of the cultural space, so that one can observe and capture a vivid manifestation of the value core in their texts.

If we consider the writer as a participant of the everyday life, he or she is not a stranger to the trivia world and events. This context reveals the compassion of the artist to society. 
This empathy in many ways defines the further creative process and, of course, the future of the creation itself represented in the public space. As the author of the book, "The Philosophy of Art" Gordon Graham puts it: "We must think of works of art as being brought to experience rather than being drawn from it. This is not meant to imply that the author works in a vacuum. It is obvious that in realistic as opposed to fantastical stories, constraints operate that reflect the way life is. Nevertheless, a novel is not to be thought of as providing as with a faithful reflection of experience or a skillful summary of it, but as obliging us to view some aspect of experience through an image which allows us to attain an illuminating perspective upon it." (Graham, 1997: 126). Within this framework, it is reasonable to question the writer's property or a mechanism, which allows him to perceive that stimulating impulse in the social and cultural field. Such impulse inspires further personal creative process and, at the same time, has significance for the society itself. Here we would like to refer to the phenomenon of aesthetic intuition, defined as the direct discretion of the concealed value-based content in the reality and in the works of art, its comprehension in the act of aesthetic perception and aesthetic evaluation, as well as in the activity of creative imagination (Beliaev, 1989: 115-116).

Values comprise the basis of culture, acting at the same time as guides in its transformation. When contradictions arise in the space of cultural values, especially in the times of the fundamental "breakage" of axiological systems, the writer's perception of these difficulties and his response through works can pinpoint the current set of values circulating in the cultural space. We regard aesthetic intuition as a social and cultural phenomenon, as well as a mediator between the literary space and the space of cultural values. A.S. Karmin defines creative intuition as "a specific cognitive process, which involves interaction of sensory images and abstract concepts in order to create fundamentally new images and concepts as opposed to the content which is derived by simple synthesis of previous perceptions, or by only logical manipulation of existing concepts" (Karmin, 2011: 12). While the author's creative intuition allows producing something new and original, aesthetic intuition connects the author's creation with reality.

Aesthetic intuition enables the writer to notice, represent and actualize in the texts various states of the space of cultural values. Fictional artistic texts reflect and embody objectively existing values, which means that in the author's consciousness the transgression of the space of cultural values takes place. According to M. Bakhtin, it is the act of effective aesthetic intuition that can "overcome the bad nonsyllabism and non-reciprocity of culture and life" (Bakhtin, 2003: 7). From which we can conclude that aesthetic intuition, by virtue of an organic combination of objective-rational and subjectivesensual principles, can serve as a sufficient basis for understanding the value content of the work for both the writer and the reader.

Aesthetic intuition of the reader allows them to find their own writer, their literature. The writer communicates the images of values to the reader, first transforming them in his creative consciousness, and then embedding them into text. The reader perceives the text and, through their own reflection and judgement, compares their value orientations with the ones presented by the author. As a result, there occurs a certain space of communication, namely a value discourse carrying the third meaning. The texts can have a greater or lesser expansion in terms of distribution and impact on the reader, but in any case, they appreciably determine the space of cultural values.

To operationalize the concept of the space of cultural values, we are to carry out a social and 
cultural analysis of texts that involves the reverse decoding of the conceptual content of literary works. This allows us to determine how the space of cultural values is reflected and embodied in fictional texts. To do this, we turn to the novels "The Love for Three Zuckerbrins" by Victor Pelevin and "Telluria" by Vladimir Sorokin, in our view, representative of the issues under consideration.

Dynamics of historical time accelerates the processes of actualization and de-actualization of values. Being stable in themselves, values nevertheless appear as a variable combination, depending on the social environment, time and place. Iu.M. Lotman in his book "Inside the Thinking Worlds" calls these processes "updating codes" (Lotman, 1996: 165), which implies the existence of different codes replacing each other. Therefore, up-to-date codes determine the consciousness of the individual, the human collective, the whole people or the epoch. In particular, updating of codes is inevitable in a social environment of essentially new phenomena. The novel "The Love for Three Zuckerbrins" demonstrates the actualization of such values as technical and information independence, the security of one's own data, the individual consciousness and its protection from interference and the uniqueness of one's own self.

In the novel, Pelevin critically reviews the dependence of the humanity on gadgets and social networks. His anti-utopia in the novel presents the future society where social media and Internet technologies have received massive proliferation. The author pays particular attention to the value aspect while describing his fictional world. Constructing the image of the future, Pelevin proposed a rather original idea: the man personifying that age takes a step inside the monitor and lives on the "desktop". This seems a logical development of the current times, where the life of a modern person passes in front of the monitor: one works, amuses himself after work and communicates with friends by means of a computer. The physical bodies of the people in the novel are placed into small apartments, similar to the "coffins" of Rodion Raskolnikov, the protagonist of "Crime and Punishment", and each morning these bodies get a matrix update corresponding to the current state of their virtual image. It is peculiar that no one deceives anyone in the world of the future; people know that they live in a computer illusion. In fact, the novel "The Love for Three Zuckerbrins" represents computer-mediated communication, a phenomenon of modernity that has significantly changed the value content of the communication culture. As S.A. Azarenko puts it: "but existence of the modern man is problematic mainly due to its absorption in information streams that are intensified electronic technologies. People cannot do without telecommunications, mobile communications, etc. Therefore the man is included in the set of information streams replacing each other, that have not only diverse, but also generally contradictory and conflict contents." (Azarenko, 2013: 1867-1878).

We can talk about the significant influence of computer-mediated communication on mutual understanding, communication style and conversation skills. In his novel Pelevin draws a different level of communication, in which people do not lie to each other and already exist inside the virtual reality. This is accomplished with the help of certain socially significant characteristics of computer-mediated communication. Firstly, anonymity, as on the Internet it is possible to be called by pseudonyms if desired. Secondly, equality of social statuses, where a schoolboy and a professor can communicate on an equal footing without seeing each other, which is impossible in the case of real-life communication. Thirdly, the opportunity to "create" a social status for themselves ("invent" another education, financial success, etc.). Lastly, 
the opportunity to stop communication, at any time going offline and so on.

The novel Telluria depicts another colorful intense feature of the modern society. The globalization of the world cultural space and the experience of the totalitarian regimes of the $20^{\text {th }}$ century have actualized the value of tolerance, the value of an equal attitude to the individual regardless of his/her social status, gender, age and color. In his novel, Vladimir Sorokin is approaching the classical ideal utopia. Many critics call this approximation the "euphoria": the image of a society that is not ideal, "fair" or "righteous", but happy - in all the fanciful uncertainty of this word. Moreover, this is not about the "common happiness" (which is always the happiness of the chosen ones), namely, the happiness of everyone primarily the individual, but also the family or any small group. Certain characters solely define happiness for themselves in Telluria, with the only restriction not to decide for another person. In part, this is consistent with a mundane axiological principle as "a person's freedom ends where the freedom of another one begins."

There is a tendency to order the space of cultural values into a structure, a desire to build a system, to objectify, to include a certain unambiguous set of values in the cultural practice, but the space of cultural values remains spontaneous and mobile in its real states. In addition, the hierarchy of phenomena in this case does not disappear, as some common judgments state it. The society grades values every time in a situational manner, as does every subject entering the space of cultural values as a sovereign person. Authors of utopias up to the $20^{\text {th }}$ century believed that the happiness of humankind lied in uniformity (it is impossible to want different if there is only one ideal). However, utopia is possible only as an inconsistent, irreducible set of isolated utopias, individual dreams, spiritual enlightenment and intimate ideas of happiness created by the imagination of everyone. Undoubtedly, these worlds will differ not only quantitatively, but also qualitatively. In the world of Telluria there is a place for everyone: princes and serfs, revolutionaries and Stalinists, dwarfs and giants, centaurs and cynocephaluses, Templars and Wahhabis, avant-garde artists and bag-makers, children and hunters for monsters, homosexuals and other people with "nonstandard orientation" - but there is no vice squads, party politics, imperial ambitions, censorship, state and church terror. All the characters get on and relatively coexist peacefully in the reality created by Sorokin, as everyone lives in the environment, within the limits that they choose.

Thus, we believe that modern Russian literature regains the functional status as one of the main factors in the formation of the space of cultural values. The very space of cultural values is actively formed and transformed depending on the actors entering into communication. Accordingly, the modern axiological dynamics is set by the diversity of the values of authors and readers, in particular by the conflicts that arise because of the discrepancy of value orientations.

In general, over the past twenty years, democratization and self-regulation of literary space has increased. On the one hand, the process of publishing a work of art (as a market product) is feasible and rational, but on the other hand, the reader's work with this product is a matter of irrational factors, such as intuition and individual features in the understanding of the book.

Based on the analysis of the novels of Victor Pelevin and Vladimir Sorokin, one can conclude that the writer intuitively perceives and figuratively reflects timely values even if there is no "cult of literature" in the society. Then, these values reappear in the cultural space, albeit indirectly, through other arts and modern information technologies and tangibly influence the axiosphere. 


\section{References}

Azarenko, S.A. (2013). Modernity: Transformation of system of values and its anthropological aspects, In Journal of Siberian Federal University. Series: The Humanities, 6 (12), 1867-1878.

Bakhtin, M.M. (2003). K filosofii postupka [To the philosophy of the act], In Sobranie sochinenii [Collected works], 1, 7-68.

Beliaev, A.A. (1989). Estetika: Slovar' [Aesthetics: dictionary]. Moscow, Politizdat, 447 p.

Cherniak, M.A. (2010). Russkaia literatura v XXI veke. Pervoe desiatiletie: diagnozy i prognozy [Russian literature in the $21^{\text {st }}$ century. The first decade: diagnoses and forecasts], In Vestnik Gertsenovskogo universiteta [Bulletin of Gertsensky university], 10, 71-76.

Graham, G. (1997). Philosophy of the Arts. New York, Routledge, 268 p.

Karmin, A.S. (2011). Intuitsiia: filosofskie kontseptsii $i$ nauchnoe issledovanie [Intuition: philosophical concepts and scientific research]. Saint Petersburg, Nauka, 901 p.

Kogan, L.N. (1969). Dukhovnoe proizvodstvo i kul'tura [Spiritual production and culture], In Voprosy dukhovnoi kul'tury sovetskikh rabochikh. [Questions of spiritual culture of Soviet workers], $1,1-13$.

Kovaleva, M.V. (2009). Fenomen kul'tury v russkoi religioznoi filosofii kontsa XIX-nachala XX veka: dissertatsiia [The phenomenon of culture in the Russian religious philosophy of the late $19^{\text {th }}$ early $20^{\text {th }}$ century: thesis]. Kursk.

Lotman, Iu.M. (1996). Vnutri mysliashchikh mirov: Chelovek-tekst-semiosfera-istoriia [Inside the thinking worlds: Man-text-semiosphere-history]. Moscow, Iazyki slavianskoi kul'tury, $447 \mathrm{p}$.

Orlova, E.O. (2006). Tsennostnoe prostranstvo kul'tury i obrazovaniia [Value space of culture and education], In Vestnik NovGU [Bulletin of Novgorod State University], 39, 90-92.

Pelevin, V.O. (2017). Liubov' k trem Tsukerbrinam [Love for three Zuckerbrins]. Moscow, E, 444 p.

Sinetskii, S.B. (2002). Metodologicheskie aspekty kul'turnoi politiki Rossii v postsovetskii period [Methodological aspects of Russia's cultural policy in the post-Soviet period], In Vestnik № 2. Cheliabinskogo instituta ekonomiki i prava. [Bulletin No. 2. Chelyabinsk institute of economics and law], 166-183.

Sorokin, V.G. (2017). Telluria [Telluria]. Moscow, Corpus, 446 p.

Surina, I.A. (2001). Tsennostnoe prostranstvo obshchestva teoretiko-metodologicheskaia kontseptsiia: dissertatsiia [The value space of society theoretical and methodological concept: thesis]. Saratov.

Tsareva, E.A. (2011). Faktor simvolicheskogo v transformatsiiakh sotsiokul'turnykh praktik: dissertatsiia [Factor of symbolic in the transformation of socio-cultural practices: thesis]. Kursk.

Tsukerman, V.S. (2011). Kul'turnoe prostranstvo rubezha XX-XXI vekov: sushchnost' i tendentsii razvitiia [Cultural space of the turn of the $20^{\text {th }}-21^{\text {st }}$ centuries: essence and development tendencies], In Vestnik ChGAKI [Bulletin of Chelyabinsk State Academy of Culture], 2 (26), 46-51. 


\section{Пространство культурных ценностей \\ в современной русской литературе}

\section{Д.А. Фунтова, С.Б. Синецкий}

Челябинский государственный институт культуры Россия, 454091, Челябинск, ул. Орджсоникидзе, $36 а$

В статье авторы развивают концепиию иенностного пространства культуры, под которым подразумевают ограниченную условной рамкой времени-места социальную среду, определяемую той или иной комбинацией иенностей. Методологическим положением статьи является тезис о возможности актуализации и деактуализации иенностей конкретного сообщества под влиянием литературного прочесса. В то же время в статье отмечается репрезентирующая функиия литературы - зависимость ее аксиологического посыла от соииально-культурной среды, в которой формировался автор художественного произведения. Утверждается, что как положительные ценности, так и отрицательные в фикииональной форме транслируются через литературные произведения и формируют ценностное пространство культуры путем создания дискурса «третьего смысла», своеобразного диалога действительности, авторов и читателей. Для апробаџии концепиии цеенностного пространства культуры авторы статьи обращаются к работам Виктора Пелевина и Владимира Сорокина-двум незаурядным представителям отечественной прозы. Решается задача декодировки и интерпретации кониептуально-содержательной основы произведений «Любовь к трем иукербринам» В. Пелевина u «Теллурия» В. Сорокина, выделения актуализированных иенностей и определения их места в ценностном пространстве современной российской культуры.

Ключевые слова: иенностное пространство культуры, современная русская литература, личность, соииальная среда, эстетическая интуииия, актуализация иенностей.

Научная спещиальность: 24.00.00 - культурология. 